\title{
PERBEDAAN KADAR HEMOGLOBIN PADA SANTRIWATI DENGAN PUASA DAUD, NGROWOT DAN TIDAK BERPUASA DI PONDOK PESANTREN TEMANGGUNG JAWA TENGAH
}

\author{
Otty Chairunnisa, Nuryanto*, Enny Probosari \\ Departemen Ilmu Gizi, Fakultas Kedokteran, Universitas Diponegoro \\ Jln. Prof. H. Soedarto, SH., Semarang, Telp (024) 76402881, Email : gizifk@undip.ac.id
}

\begin{abstract}
Background: Anemia is defined as a low level of hemoglobin in the blood. Hemoglobin levels can be affected by food intake and diatary patterns, one of which is fasting. Type of Daud fasting, Ngrowot, and no fasting, have different eating rules. The aim of this study is to figure out the differences hemoglobin levels on santriwati with Daud fasting, Ngrowot, and no fasting.

Method: This study is an observational research with cross sectional design. The subjects of the research are santriwati with the range age of 15-19 years old in Temanggung Islamic Boarding School, Central Java. The subjects are divided into three groups Daud fasting $(n=16)$, Ngrowot $(n=11)$, and no fasting $(n=16)$. Hemoglobin levels are tested by using cyanmethemoglobin method. One Way ANOVA test to determine the difference of hemoglobin levels.

Result: Hemoglobin levels in Daud fasting has mean value $12.58 \pm 1.22 \mathrm{~g} / \mathrm{dl}$, Ngrowot $12.31 \pm 1.19 \mathrm{~g} / \mathrm{dl}$, and no fasting $12.78 \pm 1.34 \mathrm{~g} / \mathrm{dl}$. Ngrowot has lower mean value than Daud fasting and no fasting. There is no significant difference between hemoglobin levels and type of fasting.

Conclusion: There was no difference in hemoglobin levels between daud fasting, ngrowot, and non fasting group.
\end{abstract}

Keyword: fasting, hemoglobin, santriwati, adolescent

\begin{abstract}
ABSTRAK
Latar belakang: Anemia adalah keadaan kadar hemoglobin dalam darah kurang dari angka normal. Kadar hemoglobin dapat dipengaruhi oleh asupan dan pola makan salah satunya adalah puasa. Jenis puasa Daud, Ngrowot, dan tidak puasa memiliki aturan makan yang berbeda. Tujuan penelitian ini adalah mengetahui perbedaan kadar hemoglobin pada santriwati dengan puasa Daud, Ngrowot, dan Tidak berpuasa.

Metode: Penelitian ini merupakan penelitian observational dengan desain cross sectional. Subjek penelitian adalah santriwati berusia 15-19 tahun di pondok pesantren Temanggung Jawa Tengah. Subjek terbagi atas kelompok puasa Daud $(n=16)$, kelompok Ngrowot $(n=11)$, dan kelompok tidak puasa $(n=16)$. Kadar hemoglobin diuji dengan metode cyanmethemoglobin. Uji One way ANOVA untuk mengetahui perbedaan kadar hemoglobin.

Hasil: Kadar hemoglobin pada kelompok puasa Daud sebesar $12.58 \pm 1.22 \mathrm{~g} / \mathrm{dl}$, Ngrowot sebesar $12.31 \pm 1.19 \mathrm{~g} / \mathrm{dl}$, dan tidak puasa sebesar $12.78 \pm 1.34 \mathrm{~g} / \mathrm{dl}$. Kelompok $\mathrm{Ngrowot}$ memiliki rerata kadar hemoglobin lebih rendah dibanding dengan puasa Daud dan tidak puasa. Tidak terdapat perbedaan yang signifikan antar kelompok.

Simpulan: Tidak terdapat perbedaan kadar hemoglobin antar kelompok dengan puasa daud, ngrowot dan tidak berpuasa.
\end{abstract}

Kata Kunci: puasa, hemoglobin, santriwati, remaja

\section{PENDAHULUAN}

Masa remaja merupakan masa terjadinya perubahan yang berlangsung cepat dalam hal pertumbuhan fisik, kognitif, dan psikososial. Masa peralihan dari anak-anak menuju dewasa yang juga ditandai dengan pertambahan massa otot, jaringan lemak tubuh, dan perubahan hormon ${ }^{1}$. World Health Organization (WHO)/United Nations Children's Emergency Fund (UNICEF) membagi kelompok remaja menjadi tiga stase, yaitu remaja awal (10-14 tahun), remaja pertengahan (14-17 tahun) dan remaja akhir (17-21 tahun $)^{2}$.

Perubahan fisik, kognitif, dan psikososial juga dapat mempengaruhi kebutuhan gizi pada remaja. Masalah gizi yang sering terjadi pada remaja diantaranya adalah malnutrisi dan anemia. Anemia adalah suatu kondisi dimana darah mengandung kadar hemoglobin yang rendah. Hemoglobin merupakan protein kaya akan zat besi yang membawa oksigen dari paru-paru ke seluruh tubuh. Pada penderita anemia, darah yang dibawa ke seluruh tubuh kurang akan oksigen dikarenakan tidak memiliki cukup zat besi untuk membentuk hemoglobin ${ }^{3}$.

Berdasarkan data World Health Organization (WHO) tahun 2015, lebih dari $30 \%$ atau 2 milyar orang di dunia berstatus anemia ${ }^{4}$. Berdasarkan hasil Riskesdas tahun 2013, prevalensi anemia di Indonesia mencapai $21,7 \%$ dengan penderita anemia berusia 514 tahun sebesar $26,4 \%$ dan $18,4 \%$ penderita berusia 
15-24 tahun ${ }^{5}$. Data Survei Kesehatan Rumah Tangga (SKRT) di Jawa Tengah tahun 2012 menyatakan bahwa prevalensi anemia pada remaja putri usia 1018 tahun sebesar $57,1 \%$ dan usia $19-45$ tahun sebesar $39,5 \%{ }^{6}$.

Anemia dapat dipengaruhi oleh beberapa faktor, diantaranya adalah asupan, infeksi, usia, menstruasi dan gaya hidup. Kurangnya asupan yang kaya akan zat besi merupakan faktor terbesar timbulnya anemia defisiensi besi. Beberapa zat gizi lain yang berkaitan anemia yaitu Protein, Zink, vitamin C, vitamin B12, dan Asam folat. Anemia yang terjadi pada masa remaja dapat mengakibatkan gangguan pertumbuhan fisik dan mental, rentan terhadap infeksi dan menurunnya tingkat konsentrasi sehingga dapat berpengaruh pada prestasi di sekolah ${ }^{7}$.

Wanita mempunyai risiko terkena anemia paling tinggi terutama pada remaja putri. Remaja putri berisiko lebih tinggi mengalami anemia karena mengalami menstruasi. Kehilangan darah saat menstruasi adalah sekitar $30 \mathrm{ml} /$ hari sehingga mengharuskan remaja putri mengkonsumsi asupan makro dan mikro yang lebih tinggi ${ }^{8}$. Anemia pada remaja putri dapat menyebabkan keterlambatan menarche dan jika remaja putri mengalami kehamilan, dapat meningkatkan risiko lahirnya bayi dengan berat badan rendah (BBLR) ${ }^{9}$.

Berdasarkan beberapa hasil penelitian menunjukkan bahwa santri merupakan salah satu kelompok remaja yang rawan terkena anemia. Hasil penelitian yang dilakukan di Pondok Pesantren AlIslam Nganjuk, menunjukkan sebanyak 92,5\% santriwati mengalami kekurangan energi, $94.0 \%$ dari responden mengalami defisit protein, dan sebanyak 97,0\% mengalami defisit zat besi. Penelitian lain menunjukkan bahwa prevalensi anemia pada santriwati sebanyak $87.5 \%$ dan di Pondok Pesantren Al-Hidayah prevalensi santriwati yang terkena anemia defisiensi zat besi sebesar $23.53 \%^{10}$. Penelitian di pondok pesantren Modern Selamat Kendal menunjukkan kejadian anemia pada santriwati sebesar $93.50 \%$ dan di pondok pesantren Putri Bani Umar Al Karim Kendal sebesar 83.90\%, sedangkan di pondok pesantren Mranggen Kabupaten Demak prevalensi anemia santriwati sebesar $74.6 \%{ }^{11}$.

Salah satu faktor yang mempengaruhi tingginya prevalensi anemi adalah asupan. Remaja di pondok pesantren memiliki kebiasaan makan yang kurang tepat seperti tingginya konsumsi makanan ringan, melewatkan sarapan, kurangnya asupan buah dan sayuran, dan makanan berkalori tinggi. Penelitian di pondok pesantren Jombang menunjukkan 16\% santri mengkonsumsi buah-buahan dalam sehari dengan jenis yang terbatas, sedangkan penelitian pada pondok pesantren Tebuireng Jombang pada tahun 2013 menunjukkan sebesar 71.4\% santri memiliki pola makan yang buruk ${ }^{12}$. Beberapa penelitian menemukan bahwa jenis makanan yang tersedia di pondok pesantren terbatas dan santri lebih sering mengkonsumsi lauk nabati dari pada lauk hewani. Selain jenis makanan, kebiasaan puasa juga merupakan salah satu faktor anemia dikarenakan perubahan asupan dan pola makan. Berdasarkan hasil survey, $>50 \%$ santriwati yang berpuasa hanya mengkonsumsi makan 1-2x sehari.

Puasa adalah menahan diri dari makan dan minum serta hal-hal lain yang membatalkannya mulai terbit fajar hingga matahari terbenam. Terdapat puasa wajib dan sunnah. Puasa wajib adalah puasa yang harus dijalankan umat muslim pada bulan Ramadhan, sedangkan puasa sunnah adalah puasa yang dilakukan dan boleh tidak dilakukan di luar bulan Ramadhan ${ }^{13}$. Macam-macam puasa sunnah yaitu puasa Senin Kamis, puasa Daud, puasa Arafah, dan Ngrowot. Puasa Daud adalah puasa yang dilakukan secara rutin tetapi berselang-seling.Ngrowot adalah keadaan dimana seseorang menghindari konsumsi beras dan turunannya namun tetap mengkonsumsi jenis makanan lain. ${ }^{14}$

Berdasarkan uraian di atas peneliti ingin mengetahui perbedaan kadar hemoglobin pada santri putri dengan puasa daud, ngrowot, dan tidak berpuasa di Pondok Pesantren Temanggung Jawa Tengah.

\section{METODE}

Penelitian merupakan analitik observasional dengan rancangan cross sectional yang dilakukan di tiga Pondok Pesantren Kabupaten Temanggung Jawa Tengah yaitu pondok pesantren Safinatul Jabbal, Fathul Mubarok, dan Miftakhurrosyidin. Santriwati mengikuti pengukuran antropometri dan wawancara menggunakan kuesioner, serta pengambilan sampel darah. Populasi terjangkau penelitian adalah santri putri yang bertempat tinggal di pondok pesantren Kabupaten Temanggung usia 15-19 tahun. Sampel dibedakan menjadi 3 kelompok, yaitu yang melakukan puasa Daud, Ngrowot, dan yang tidak melakukan puasa minimal 3 bulan. Jumlah sampel dipilih menggunakan metode purposive sampling.

Total sampel sebanyak 43 santriwati yaitu 16 dengan puasa daud, 11 dengan ngrowot, dan 16 tidak berpuasa. Pondok pesantren Safinatul Jabbal terdapat 9 santri dengan puasa daud, 2 ngrowot, dan 6 tidak puasa. Pondok pesantren Fathul Mubarok terdapat 1 santriwati dengan puasa daud, 2 ngrowot, dan 10 tidak berpuasa. Pondok Pesantren Miftakhurrosyidin terdapat 6 santriwati dengan puasa daud dan 7 ngrowot.

Penelitian diawali dengan skrining berupa pengambilan data diri subjek penelitian dan pengukuran antropometri berupa berat badan dan 
tinggi badan. Penelitian kemudian dilanjutkan dengan wawancara menggunakan kuesioner semi quantitative food frequency questionnair ( $S Q-F F Q$ ) untuk mengetahui asupan makro dan mikro. Penelitian dilanjutkan dengan pengambilan darah yang dilakukan oleh petugas pengambil darah dari laboratorium yang terpercaya. Darah diambil melalui vena antecubital sebelah kiri sebanyak $3 \mathrm{ml}$. Kemudian sampel darah di periksa kadar hemoglobin dengan metode sianmethemoglobin. Kadar normal hemoglobin untuk remaja wanita adalah adalah 12 $\mathrm{g} / \mathrm{dL}$, dikategorikan anemia apabila kurang dari 12 g/dL. Data yang sudah dikumpulkan kemudian di uji beda menggunakan ANOVA yang sebelumnya di uji normalitas menggunakan Shappiro Wilk.

\section{HASIL}

Berdasarkan data yang diperoleh, diketahui karakteristik subjek penelitian adalah sebagai berikut.

Tabel 1. Karakteristik Subjek

\begin{tabular}{|c|c|c|c|c|c|c|}
\hline \multirow[t]{2}{*}{ Variabel } & \multicolumn{2}{|c|}{ daud } & \multicolumn{2}{|c|}{ Ngrowot } & \multicolumn{2}{|c|}{ tidak puasa } \\
\hline & $\mathbf{n}$ & $\%$ & $\mathbf{n}$ & $\%$ & $\mathbf{n}$ & $\%$ \\
\hline \multicolumn{7}{|l|}{ Usia (tahun) } \\
\hline 15 & 3 & 18.75 & 0 & 0 & 5 & 31.25 \\
\hline 16 & 3 & 18.75 & 1 & 9.10 & 2 & 12.5 \\
\hline 17 & 7 & 43.75 & 4 & 36.36 & 3 & 18.75 \\
\hline 18 & 3 & 18.75 & 6 & 54.54 & 5 & 31.75 \\
\hline 19 & 0 & 0 & 0 & 0 & 1 & 6.25 \\
\hline \multicolumn{7}{|c|}{ Lama Puasa (bulan) } \\
\hline $0-6$ & 7 & 43,75 & 4 & 36,36 & 0 & 0 \\
\hline $7-12$ & 6 & 37,5 & 0 & 0 & 0 & 0 \\
\hline$>12$ & 3 & 18,75 & 7 & 63,63 & 0 & 0 \\
\hline
\end{tabular}

Tabel 2. Rerata Berat Badan, Tinggi Badan, dan Status Gizi Pada Ketiga Kelompok

\begin{tabular}{lccc}
\hline \multicolumn{1}{c}{ Antropometri } & daud & Ngrowot & tidak puasa \\
\cline { 2 - 4 } & rerata \pm SB & rerata \pm SB & rerata \pm SB \\
\hline Berat Badan $(\mathrm{kg})$ & $47.15 \pm 5.57$ & $49.28 \pm 4.78$ & $49.94 \pm 5.19$ \\
Tinggi Badan $(\mathrm{cm})$ & $151.5 \pm 5.07$ & $149.8 \pm 4.17$ & $150.3 \pm 7.07$ \\
$I M T / U$ & $-0.32 \pm 0.67$ & $0.21 \pm 0.59$ & $0.18 \pm 0.73$ \\
\hline
\end{tabular}

Tabel 3. Rerata Kadar Hemoglobin pada

Ketiga Kelompok Penelitian

\begin{tabular}{ccc}
\hline Puasa & Kadar Hemoglobin & $p$ \\
\cline { 2 - 2 } & rerata \pm SB & \\
\hline daud & $12.58 \pm 1.22$ & \\
ngrowot & $12.31 \pm 1.19$ & $0,64^{\mathrm{a}}$ \\
Tidak berpuasa & $12.78 \pm 1.34$ & \\
\hline
\end{tabular}

${ }^{\mathrm{a} O n e}$ Way Anova

Tabel 1 menunjukkan bahwa subjek penelitian berusia 15-19 tahun dengan rata-rata pada kelompok Daud 16 tahun, Ngrowot 17 tahun dan tidak puasa 16 tahun. Untuk rata-rata lama puasa Daud yaitu 10 bulan dan ngrowot 15 bulan.
Subjek yang menjalankan ngrowot rata-rata di atas satu tahun lamanya. Sedangkan untuk puasa daud yang dilaksanakan subjek rata-rata selama kurang dari tujuh bulan.

Tabel 2 dapat diketahui bahwa status gizi remaja tiap kelompok berdasarkan IMT/U rerata sebesar -0,32 untuk kelompok daud, 0,21untuk kelompok ngrowot, dan 0,18 untuk kelompok tidak puasa dimana rearata ketiga kelompok dalam kategori normal.

Tabel 3 menunjukkan bahwa tidak ada perbedaan yang bermakna antara kadar Hemoglobin dengan jenis puasa. Rerata kadar hemoglobin terendah pada kelompok Ngrowot yaitu sebesar 12,31 $\mathrm{g} / \mathrm{dl}$.

Tabel 4. Proporsi Anemia pada Ketiga Kelompok

\begin{tabular}{lccccc}
\hline & \multirow{2}{*}{ Kelompok } & \multicolumn{3}{c}{ Kategori } \\
\cline { 2 - 5 } & & Normal & \multicolumn{3}{c}{ Anemia } \\
\cline { 2 - 5 } & Daud & 12 & \% & n & \% \\
Ngrowot & 8 & 75 & 4 & 25 \\
Tidak puasa & 12 & 73 & 3 & 27 \\
\hline
\end{tabular}


Tabel 5. Rerata Asupan Zat Gizi Perhari pada Ketiga Kelompok

\begin{tabular}{lcccc}
\hline Karakteristik Variabel & $\begin{array}{c}\text { Daud } \\
(\mathbf{n = 1 6})\end{array}$ & $\begin{array}{c}\text { Ngrowot } \\
(\mathbf{n = 1 1})\end{array}$ & $\begin{array}{c}\text { Tidak Puasa } \\
(\mathbf{n = 1 6})\end{array}$ & $\boldsymbol{p}$ \\
\cline { 2 - 4 } & rerata \pm SB & rerata \pm SB & rerata \pm SB & \\
\hline Protein (gram) & $62,35 \pm 38,34$ & $53,90 \pm 32,14$ & $55,42 \pm 31,00$ & $0,77^{\mathbf{a}}$ \\
Zinc (mg) & $6,99 \pm 4,04$ & $6,09 \pm 3,11$ & $6,77 \pm 3,53$ & $0,81^{\mathbf{a}}$ \\
Vitamin C (mg) & $61,98 \pm 50,73$ & $65,15 \pm 56,37$ & $85,90 \pm 73,73$ & $0,51^{\mathbf{a}}$ \\
Vitamin B12(mcg) & $3,03 \pm 4,29$ & $3,77 \pm 3,72$ & $1,93 \pm 1,12$ & $0,35^{\mathbf{a}}$ \\
Folat (mcg) & $140,47 \pm 113,78$ & $154,02 \pm 85,08$ & $143,71 \pm 99,16$ & $0,94^{\mathbf{a}}$ \\
Besi (mg) & $14,80 \pm 11,63$ & $12,69 \pm 11,87$ & $14,86 \pm 13,61$ & $0,88^{\mathbf{a}}$ \\
\hline
\end{tabular}

${ }^{\mathrm{a} O n e ~ W a y ~ A n o v a ~}$

Tabel 6. Gambaran Kategori Asupan pada Ketiga Kelompok

\begin{tabular}{llcccccc}
\hline Variabel & Kelompok & \multicolumn{2}{c}{ Daud } & \multicolumn{2}{c}{ Ngrowot } & \multicolumn{2}{c}{ Tidak Puasa } \\
& & $\mathbf{n}$ & $\mathbf{\%}$ & $\mathbf{n}$ & $\mathbf{\%}$ & $\mathbf{n}$ & \% \\
\hline Energi & Kurang & 7 & 43,75 & 7 & 63,7 & 8 & 50 \\
& Cukup & 6 & 37,5 & 3 & 27,2 & 6 & 37,5 \\
\multirow{4}{*}{ Protein } & Lebih & 3 & 18,75 & 1 & 9,1 & 2 & 12,5 \\
& Kurang & 9 & 56.25 & 8 & 72,72 & 10 & 62,5 \\
& Cukup & 3 & 18,75 & 1 & 9.09 & 4 & 25 \\
Seng & Lebih & 4 & 25 & 2 & 18,18 & 2 & 12.5 \\
& Kurang & 15 & 93.75 & 11 & 100 & 15 & 93.75 \\
& Cukup & 1 & 6.25 & 0 & 0 & 1 & 6.25 \\
Vit C & Lebih & 0 & 0 & 0 & 0 & 0 & 0 \\
& Kurang & 9 & 56.25 & 7 & 63.63 & 6 & 37.5 \\
& Cukup & 4 & 25 & 1 & 9.09 & 3 & 18.75 \\
Vit B12 & Lebih & 3 & 18,75 & 3 & 18.75 & 7 & 43.75 \\
& Kurang & 10 & 62.5 & 5 & 45.45 & 9 & 56.25 \\
\multirow{4}{*}{ Asam Fola } & Cukup & 1 & 6.25 & 1 & 9.09 & 4 & 25 \\
& Lebih & 5 & 31.25 & 5 & 45.45 & 3 & 18.75 \\
& Kurang & 14 & 87.5 & 10 & 90.90 & 15 & 93.75 \\
Zat Besi & Cukup & 2 & 12.5 & 1 & 9.09 & 1 & 6.25 \\
& Lebih & 0 & 0 & 0 & 0 & 0 & 0 \\
& Kurang & 12 & 75 & 10 & 90.90 & 14 & 87.5 \\
& Cukup & 2 & 12.5 & 0 & 0 & 0 & 0 \\
& Lebih & 2 & 12.5 & 1 & 9.09 & 2 & 12.5 \\
\hline
\end{tabular}

Tabel 4 menunjukkan bahwa subjek dengan kadar hemoglobin normal lebih banyak pada kelompok daud dan tidak berpuasa dibandingan dengan kelompok ngrowot.

Tabel 5 menunjukkan bahwa tidak terdapat perbedaan yang bermakna antara asupan protein, $\mathrm{Zn}$, Vitamin C, Vitamin B12, Folat dan Fe dengan jenis puasa.

Tabel 6 menunjukkan bahwa sebagian besar zat gizi pada ketiga kelompok termasuk dalam kategori kurang.

\section{PEMBAHASAN}

Puasa Daud merupakan puasa yang dilaksanakan dengan cara berselang-seling, sehari puasa dan hari berikutnya tidak. Menjalankan puasa daud harus menahan makan dan minum dari sebelum subuh hingga tenggelamnya matahari ${ }^{15}$. Hasil dari penelitian menunjukkan sebagian besar santriwati mengkonsumsi makanan utama pada saat sahur dan buka puasa. Keadaan tersebut secara tidak langsung mengubah frekuensi makan santriwati menjadi $2 \mathrm{x} /$ hari pada saat menjalankan puasa. Tidak sedikit pula santriwati yang melewatkan makan sahur sehingga mereka hanya mengkonsumsi makanan utama satu kali dalam sehari.

Ngrowot adalah suatu kepercayaan yang menganut paham tidak mengkonsumsi nasi dan turunanannya. Contoh makanan yang berbahan dasar beras adalah bihun, tepung beras, lontong, dan lainlain. Pada kelompok Ngrowot ini tidak mengalami perubahan frekuensi makan, yaitu santri tetap diizinkan mengonsumsi makanan selama 24 jam, namun jenis makakanan dibatasi. Jika santriwati melanggar aturan puasa, maka puasanya dianggap batal dan harus mengulang di hari berikutnya ${ }^{14}$.

Puasa memiliki beberapa manfaat untuk kesehatan diantaranya yang pertama adalah untuk detoksifikasi, kadar racun akan berkurang.. Keteraturan dan kontinuitas pada saat puasa membantu pembuangan racun dari dalam tubuh lebih. Kedua, mempercepat regenerasi sel, pada saat 
manusia berpuasa, maka tidak ada kalori yang masuk ke dalam tubuh, maka tubuh akan merombak persediaan makanan. Lemak dibakar untuk membentuk energi setelah cadangan glukosa dari karbohidrat menurun, cadangan ini setiap saat akan dibakar menjadi energi jika tubuh tidak mendapat pasokan makanan dari luar. Dengan digunakannya cadangan energi dari tubuh membuat sel-sel penyusun akan ter regenerasi menjadi sel sel yang baru, cara ini disebut peremajaan sel. ${ }^{16}$

Hasil dari penelitian yaitu tidak terdapat perbedaan kadar hemoglobin antara subjek dengan puasa daud, ngrowot, dan tidak puasa. Hasil ini sesuai dengan penelitian yang dilakukan di Sleman Yogyakarta, yaitu tidak terdapat perbedaan kadar hemoglobin antara kelompok yang berpuasa daud, dengan kelompok yang tidak berpuasa ${ }^{17}$.

Terdapat juga beberapa penelitian yang menunjukkan hasil berbeda. Seperti penelitian yang dilakukan di Iran yang menghubungakan puasa Ramadhan dengan hemogobin, hasilnya terdapat penurunan Hemoglobin yang signifikan pada hari ke 3 dan hari ke 15 berpuasa. Sedangkan pada penelitian Asian Journal od Science of Medicine tahun 2011, menunjukkan terdapat kenaikan Hemoglobin sebesar $6,3 \%$ dari sebelum puasa hingga setelah puasa Ramadhan $^{18}$.

Hemoglobin merupakan protein yang mengandung zat besi di dalam sel darah merah yang berfungsi sebagai pengangkut oksigen dari paru-paru ke selurh tubuh. Hemoglobin rendah dapat disebut dengan anemia. Anemia terdiri dari anemia zat gizi dan anemia non gizi ${ }^{8}$. Anemia zat gizi disebabkan karena kurangnya asupan yang berhubungan dengan pembentukkan hemoglobin seperti zat besi, Zink, Vitamin C, Vitamin B12, dan Asam Folat. Berdasarkan suatu penelitian yang dilakukan di SMKN 2 Yogyakarta,terdapat hubungan antara pola makan dengan kejadian anemia. Pola makan yang buruk seperti tidak sarapan di pagi hari, atau melewatkan makan malam, dapat berpengaruh pada asupan zat gizi sehingga dapat menimbulkan anemia $^{19}$.

Subjek yang mengalami anemia pada penelitian ini berjumlah 11 orang, yaitu 4 dari kelompok daud, 4 dari kelompok ngrowot, dan 4 dari kelompok tidak berpuasa. Kadar hemoglobin terendah pada penelitian ini ini yaitu $10 \mathrm{~g} / \mathrm{dl}$ pada kelompok puasa Daud dan Ngrowot. Berdasarkan dari data asupan, subjek dengan puasa daud dan ngrowot lebih sedikit mengkonsumsi makanan dibandingkan dengan yang tidak berpuasa berdasarkan kuantitatas maupun kualitas. Asupan yang kurang dapat mempengaruhi keseimbangan zat gizi dalam tubuh dan dapat menurunkan kadar hemoglobin, sehingga terjadi anemia pada kedua kelompok tersebut ${ }^{20}$.

Berdasarkan hasil penelitian, santriwati yang menjalankan puasa ngrowot mengganti konsumsi nasi dengan jagung, namun tidak disertai dengan lauk. Hal ini telah menjadi kebiasaan bagi para santriwati. Jika mereka mengkonsumsi makanan selain jagung, akan dikonsumsi di luar jam makan utama. Terkadang pada saat jam makan santri telah tiba, para santriwati yang berpuasa ngrowot juga ikut makan bersama namun hanya mengkonsumsi lauknya saja.

Tabel hasil menunjukkan bahwa asupan subjek yang menjalankan Ngrowot tergolong pada kategori kurang pada semua zat gizi. Variasi makanan yang rendah dapat mengakibatkan kurangnya zat gizi pada tubuh dan dapat menyebabkan faktor timbulnya anemia. Sumber bahan makanan yang dikonsumsi oleh santriwati yang menjalankan ngrowot selain jagung adalah mie instan. Konsumsi mie instan santriwati dapat mencapai $2 x$ dalam seminggu.

Untuk penyelenggaraan makan pada kempok ngrowot tidak seperti puasa daud dan tidak berpuasa. Pondok pesantren hanya menyediakan jagung yang kemudian diolah oleh santri yang berpuasa ngrowot. Santriwati dengan ngrowot juga diijinkan untuk mengkonsumsi lauk dan sayur yang disajikan untuk santri lain yang tidak ngrowot pada saat jam makan. Jenis lauk dan sayur yang sering dikonsumsi.

Santri yang ada di pesantren mendapatkan jatah makan 2x sehari, dan santri dibebaskan membeli makanan di dalam pondok (kantin) dan di luar pondok pesantren. Makanan yang dijual di kantin berupa makanan ringan yang rendah akan zat gizi, hal tersebut merupakan salah satu faktor yang menyebabkan rendahnya asupan zat gizi pada santriwati.

Berdasarkan hasil penelitian, santriwati dengan status gizi normal dengan santriwati dengan status gizi overweight memiiki rata-rata asupan energi dan zat gizi yang hampir yang sama. Tingkat kecukupan asupan protein pada kelompok daud, ngrowot dan tidak puasa memiliki persentase masing masing 18,75 , 9,09\%, dan $25 \%$. Persentase tersebut masih jauh dari batas normal yaitu $80 \%$.

Protein adalah salah satu zat gizi yang dibutuhkan dalam jumlah besar yaitu $15 \%$ dari kebutuhan orang normal. Protein berperan sebagai transferin yang disintesis di hati. Transferin mengangkut besi dalam sirkulasi ke tempat-tempat yang membutuhkan, seperti dari usus ke sumsum tulang untuk membentuk hemoglobin yang baru. Sumber makanan yang mengandung protein tinggi diantaranya daging merah, ikan, tempe, tahu, kacangkacangan, dan lain sebagainya. ${ }^{8}$ 
Pondok pesantren tempat penelitian menyediakan makanan utama untuk santri sebanyak 2x dalam sehari. Menu setiap hari berbeda, namun dengan bahan makanan yang sama. Sumber protein yang dikonsumsi oleh santriwati lebih banyak dari sumber nabati yaitu tahu dan tempe. Sedangkan sayur yang biasa disediakan yaitu sop atau jipan. Sumber protein hewani tersedia pada hari-hari besar atau perayaan tertentu, seperi telur, daging sapi atau ayam. Penyajian makanan untuk santriwati yaitu menggunakan nampan yang berisi nasi, lauk, dan sayur untuk 4-5 orang.

Asupan protein akan masuk ke dalam tubuh dan dipecah menjadi asam amino. Asam amino digunakan untuk hampir setiap proses metabolisme dalam tubuh. Protein hewani memiliki struktur sel yang lebih mudah dicerna oleh tubuh. protein hewani dianggap sebagai sumber protein yang lengkap karena mengandung semua asam amino esensial yang dibutuhkan tubuh untuk berfungsi secara efektif ${ }^{21}$.

Zat gizi lain yang berhubungan dengan pembentukkan hemoglobin diantaranya zat besi. Berdasarkan hasil penelitian asupan zat besi tergolong kurang mencapai 90\% pada kelompok ngrowot, sedangkan pada kelompok tidak puasa $87,5 \%$ dan $75 \%$ pada kelompok Daud. Kurangna zat besi pada kelompok ngrowot dikarekanan santriwati terbiasa mengganti beras yang biasa dikonsumsi dengan jagung. Konsumsi jagung ini jarang bersamaan dengan bahan makanan atau lauk lain seperti tempe, tahu, dan sayur. Bahan hewani pondok tidak menyediakan setiap hari. Terdapat 3 santriwati yang mengalami anemia dengan kadar $\mathrm{Hb}$ masing masing 10,5 g.dl, $10 \mathrm{~g} / \mathrm{dl}$ dan $11,5 \mathrm{~g} / \mathrm{dl}$. Penelitian ini sejalan dengan penelitian menyatakan bahwa ada hubungan antara asupan Fe dengan kejadian anemia yang menunjukkan kurangnya konsumsi $\mathrm{Fe}$ akan memungkinkan terjadinya anemia.

Zink memiliki fungsi dan kegunaan penting bagi tubuh yang merupakan salah satu mikronutrien. Zink berperan banyak pada pembentukkan sel seperti kulit, mukos saluran cerna dan lain-lain. Defisiensi Zink dapat berdampak pada penurunan nafsu makan sampai pada gangguan sistem pertahanan tubuh. Mineral zink merupakan salah satu nutrien penting yang diperlukan oleh tubuh dalam menjaga dan memelihara kesehatan. Protein hewani terutama daging, hati, kerang, dan telur merupakan sumber zink yang paling baik. Pada albumin terdapat kandungan zink sekitar $70 \%$ sehingga kondisi konsentrasi albumin dalam darah dapat mempengaruhi level zink seseorang. Jenis protein yang dikonsumsi akan berpengaruh terhadap zink ${ }^{22}$.

Hasil asupan menunjukkan pada semua kelompok penelitian kurang mengkonsumsi bahan makanan sumber hewani seperti daging, hati, ikan dan susu. Pada subjek dengan kelmpok Ngrowot $100 \%$ kekurangan asupan zink. Defisiensi atau kekurangan zink di dalam tubuh dapat terjadi karena asupan zink yang kurang, gangguan di dalam penyerapan, atau meningkatnya kebutuhan serta ekskresi zink.

Penelitian ini sejalan dengan penelitian yang dilakukan di Batang yaitu antara asupan zink dengan anemia pada remaja yang menyatakan bahwa ada hubungan asupan zink dengan kejadian anemia sesuai dengan teori interaksi tidak langsung antara zink dan Fe dapat terjadi melalui peran zink dalam sintesis berbagai protein termasuk protein pengangkut besi yaitu transferin ${ }^{23}$.

Vitamin $\mathrm{C}$ sangat membantu penyerapan besi non heme dengan mereduksi besi ferri menjadi ferro dalam usus halus sehingga mudah diabsorpsi. Tingginya persentase asupan vitamin $\mathrm{C}$ pada kelompok tidak puasa mencapai $43,75 \%$ berlebih disebabkan karena tidak terbatasnya waktu untuk mengkonsumsi makanan, dan pada hasil penelitian subjek tidak berpuasa banyak mengkonsumsi jajanan dari luar pondok seperti es jeruk, dan makanan lain yang kaya vitamin $C$ seperti cabai.

Vitamin $\mathrm{C}$ sangat membantu penyerapan besi non heme dengan mereduksi besi ferri menjadi ferro dalam usus halus sehingga mudah diabsorpsi. Vitamin $\mathrm{C}$ menghambat pembentukan hemosiderin yang sukar dimobilisasi untuk membebaskan besi bila diperlukan. Absorpsi besi dalam bentuk non heme meningkat empat kali lipat bila ada vitamin $\mathrm{C}^{22}$.

Asam folat dan vitamin B12 merupakan zat gizi yang saling berpengaruh di dalam tubuh. Defisiensi salah satu atau keduanya pada waktu yang bersamaan dapat menyebabkan anemia yaitu anemia makrositik megaloblastik dan kegagalan sintesis DNA. Faktor yang dapat menyebabkan defisiensi tersebut yaitu salah satunya asupan ${ }^{24}$.

Pada ketiga kelompok penelitian ini yaitu Daud, Ngrowot, dan Tidak puasa baik asam folat maupun vitamin B12 masih tergolong kurang $(<80 \%)$ Kurangnya asam folat dan vitamin B12 tersebut dikarenkaan kurangnya variasi bahan makanan yang dikonsumsi. Sehari-hari santriwati makan makanan utama $2 \mathrm{x}$ /hari yang disediakan oleh pondok. Lauk yang sering dikonsumsi yaitu tahu dan tempe, sayur yang biasa dikonsumsi yaitu sop, sayur bening, dan jipan dimana komposisi sayur lebih sedikit dibandingkan dengan kuah sayur tersebut.

Hasil uji beda menunjukkan bahwa tidak ada perbedaan asupan zat gizi yang signifikan antara kelompok Daud, Ngrowot dan Tidak Berpuasa (p>0,05). Hal ini disebabkan rerata asupan zat gizi kedua kelompok hampir sama secara jumlah sehingga tidak jauh beda. 


\section{SIMPULAN}

Tidak ada perbedaan asupan zat gizi dan kadar hemoglobin pada kelompok puasa Daud, Ngrowot, dan tidak berpuasa. Rerata kadar hemoglobin pada ketiga kelompok dalam batas normal.

\section{SARAN}

Sebaiknya subjek kelompok Daud dan Ngrowot dengan anemia lebih banyak mengonsumsi makanan terutama sumber protein hewani dan untuk kelompok tidak berpuasa dengan anemia pemilihan makanan dianjurkan sumber protein dengan mengurangi pengolahan makanan yang menggunakan minyak, dan untuk santriwati dengan puasa Daud disarankan untuk tidak melewatkan sahur agar jumlah asupan energi terpenuhi.

\section{DAFTAR PUSTAKA}

1. Hashmi S. Adolescence : An Age of Storm and Stress. 2013;2(1).

2. Hardinsyah, Supariasa i DN. Ilmu Gizi Teori dan Aplikasi. Jakarta; 2016. 160 p.

3. Nelima. Prevalence and Determinants of Anaemia among Adoloscent Girls in Secondary Schools in Yala Division Siaya District. J Food Nutr Sci. 2015;3(1):1-9.

4. Organization WH. World Health Statistics. 2015;

5. No TitleKemenkes RI., 2014. Profil Kesehatan Indonesia 2014.[Online] Available at: http://www.depkes.go.id/resources/download/p usdatin/profil-kesehatan-indonesia/profilkesehatan-indonesia-2014.pdf.

6. Dinas Kesehatan Provinsi Jawa Tengah 2014. Profil Kesehatan Provinsi Jawa Tengah 2013. Semarang: Dinkes Prov. Jateng.

7. Bindra V. Anemia in Adolescence. :18-9.

8. Citrakesumasari. Anemia Gizi, Masalah dan Pencegahannya. Yogyakarta; 2012.

9. Engidaw MT, Wassie MM, Teferra AS. Anemia and associated factors among adolescent girls living in Aw-Barre refugee camp, Somali regional state, Southeast Ethiopia. PLoS One. 2018;13(10): 1-12.

10. Sumarmi S. HUBUNGAN STATUS GIZI DENGAN KEJADIAN DARUL ULUM PETERONGAN JOMBANG. 2016;1(1).

11. Astuti R, Rosidi A. Faktor Resiko Anemia Pada
Siswi Pondok Pesantren Putri Kecamatan Mranggen Kabupaten Demak Jawa Tengah. The Second Research Coloquium 2015. ISSN 24079189.

12. Ana M, Pawiono, Iswanto. The Relationship Between Manner of Consume and Phenome of Typhoid at Tebuireng Islamic Boarding School Jombang.

13. Ghr F, Yousfi H, Vakili M, F AN. The Effect of Ramadan Fasting on Hemoglobin, Hematocrit and Blood Biochemical Parameters. 2006;6(2):21-7.

14. Pondok DI, Luqmaniyah P, No JK, Yogyakarta $K$. BUDAYA NGROWOT NGROWOT TRADITION IN NEUROSCIENCE STUDY IN LUQMANIYAH ISLAMIC BOARDING SCHOOL , : :125-47.

15. Aminati A. Recomendation of Daud Fasting in Hadith. UIN Walisongo. 2015;

16. Fond G, Macgregor A, Leboyer M, Michalsen A. Fasting in Mood Disorders: Neurobiology and Effectiveness. 2013.

17. Fidianingsih I, Novita R, Addina M, Jamil N. Daud Fasting on Haematological, Renal, and Lipid Profile in Menopausal Women. 2017;11.

18. Khaled T, Stephen. Effects of Ramadan Fasting on Biochemical and Anthropometric Parameters in Physically Active Men. 2011;

19. Tiaki, Khatim N, Ismarwati. Hubungan Pola Makan dengan Kejadian Anemia pada Remaja Putri Kelas XI di SMKN 2 Yogyakarta. 2017;

20. Your Guide to Anemia. US Dep Heal Hum Serv. 2011;

21. Mahan LK, Stump SE. Krause's and Nutrition Therapy. 12 th ed. USA: Saunders; 2008. p.9192.

22. Grooper Smith, Advanced Nutrition and Human Metabolism. 6th ed. Belmont: Wadsworth Publishing; 2012.

23. Trisnawati . Publikasi Karya Ilmiah Hubungan Asupan Fe, Zinc, Vitamin C Dan Status Gizi Dengan Kejadian Anemia Pada Remaja Putri Di SMP Negeri 4 Batang.2014.

24. Moll R, Davis B. Iron, vitamin B12 and folate. Clinical Science [nternet]. Available from; http://dx.doi.org/10.1016/j.mpmed.2008.12.009 